TORRES, JLR; CIABOTTI, ED; GOMES, FRC; LEAL JUNIOR, ALB; VIEIRA, DMS; COSTA, LL. 2017. Physico-chemical attributes of no-till Brassica crops cultivated after various cover crops. Horticultura Brasileira 35: 252-257. DOI - http://dx.doi.org/10.1590/S0102-053620170216

\title{
Physico-chemical attributes of no-till Brassica crops cultivated after various cover crops
}

\author{
José LR Torres; Elaine D Ciabotti; Fernando RC Gomes; André LB Leal Junior; Dinamar MS Vieira; \\ Luciene L Costa \\ Instituto Federal do Triângulo Mineiro (IFTM), Uberaba-MG, Brasil; jlrtorres@iftm.edu.br; elaine@iftm.edu.br; \\ fernandorodriguesdacunha@hotmail.com; andrebenaventana@gmail.com; marcinha_0202@hotmail.com; luciene@iftm.edu.br
}

\begin{abstract}
Cauliflower and cabbage require high amounts of nutrients in short periods of time; however, the intensive use of inorganic fertilizers can cause nutritional imbalances in these crops and reduce the quality of the final product. This study evaluated the chemical composition and yield of no-till cauliflower and cabbage grown on residues of various cover crops in Uberaba, Minas Gerais State, Brazil. The experimental design was randomized blocks with four cover crops (sunn hemp, brachiaria, pearl millet and fallow) and two main crops (cauliflower and cabbage). The treatments were evaluated on plots of $20 \mathrm{~m}^{2}$ with four replications. The following traits were analyzed after harvest: moisture (MO), ash (ASH), lipid (LIP), crude fiber $(\mathrm{CF})$, protein $(\mathrm{PTN})$, carbohydrates (CARB), total soluble solids (TSS), total titratable acidity (TTA), $\mathrm{pH}$, ascorbic acid (AA), head fresh weight (HFW), head dry weight (HDW) and yield. Cauliflower cultivated on sunn hemp residues produced high levels of LIP, PTN, CARB, TSS and TTA, whereas cauliflower cultivated on brachiaria and millet residues demonstrated high AA levels when compared to the treatment with sunn hemp residues. In the aerial part, cabbage presented significantly higher levels of CARB, TTA and AA when cultivated on brachiaria residues, whereas PTN levels were higher on sunn hemp residues. The cultivation of cauliflower and cabbage on cover crop residues affected positively most of the chemical attributes of the evaluated crops when compared to the fallow treatment, although the highest yield and AA levels were observed when the crops were cultivated on brachiaria residues.
\end{abstract}

Keywords: Brassica oleracea var. botrytis, Brassica oleracea var. capitata, crop residues, nutrient cycling, plant quality.

\section{RESUMO}

Atributos físico-químicos de Brassicas cultivadas sobre diferentes coberturas em plantio direto

A couve-flor e o repolho são plantas que necessitam de elevados aportes de nutrientes em curtos períodos de tempo; contudo, o uso intensivo de fertilizantes inorgânicos pode causar o desequilíbrio nutricional destas plantas e influenciar a qualidade do produto final. Neste estudo avaliou-se a composição química e a produtividade da couve-flor e do repolho cultivados sobre os resíduos de diferentes plantas de coberturas do solo em sistema plantio direto, no município de Uberaba-MG. Com delineamento de blocos ao acaso em esquema fatorial, utilizaram-se quatro plantas de coberturas (crotalária juncea, braquiária, milheto e pousio) e duas culturas (couve-flor e repolho), com quatro repetições, em parcelas de $20 \mathrm{~m}^{2}$. Após a colheita, as plantas foram levadas ao laboratório para avaliações da umidade, cinzas, lipídeos (LIP), fibra bruta (FB), proteínas (PTN), carboidratos $(\mathrm{CHO})$, sólidos solúveis totais (SST), acidez total titulável (ATT), pH e ácido ascórbico (AA), massa fresca da cabeça (MFC), massa seca da cabeça (MSC) e produtividade (Prod). As plantas de couve-flor cultivada sobre os resíduos de crotalária juncea apresentaram maiores teores de LIP, PTN, CHO, SST e ATT, enquanto que nos resíduos de braquiária e milheto, os teores de AA foram maiores quando comparados a crotalária. As plantas de repolho apresentaram valores significativamente maiores na sua parte aérea de $\mathrm{CHO}$, ATT e AA quando cultivadas sobre os resíduos de braquiária, enquanto que para a PTN se destacou com o plantio sobre os resíduos da crotalária juncea. O cultivo da couve-flor e repolho sobre os resíduos de plantas de cobertura alteraram positivamente a maioria dos atributos químicos das culturas, quando comparados à área deixada em pousio, sendo que os melhores resultados de produtividade e AA ocorreram quando as culturas foram cultivadas sobre resíduos de braquiária.

Palavras-chave: Brassica oleracea var. botrytis, Brassica oleracea var. capitata, resíduos culturais, ciclagem de nutrientes, qualidade da planta.

Received on January 13, 2016; accepted on September 26, 2016

$\mathrm{T}$ he nutritional quality of cauliflower and cabbage depends on various physical, chemical and sensory attributes. These plants present a high nutritional and commercial value, and together with potatoes, tomatoes and lettuce are among the most consumed vegetables in Brazil (Carvalho et al., 2013). They are typically cultivated in regions with cold or mild climate, but there are cultivars appropriate for warmer regions.

Cauliflower, broccoli and cabbage are the most important Brassica crops cultivated in Brazil. They are excellent 
sources of vitamin A, potassium, iron, calcium, fiber and phytochemicals rich in citric acid, ascorbic acid, and calcium salts (Manolopoulou \& Varzakas, 2011). P-coumaric acid and rutin present in these plants strengthen the immune system, reduce the risk of heart attack and prevent various types of cancer (Oms-Oliu et al., 2010).

Analyzing physico-chemical composition of noble parts of several crops, Storck et al. (2013) report the following levels of carbohydrates (CARB), crude fiber (CF), proteins (PTN), lipids (LIP), ash (ASH), and moisture (MO): 4.5, 2.4, 1.9, 0.2, 0.6, $92.8 \%$ in cauliflower, and 4.0, 2.9, 3.6, $0.3,91.2 \%$ in broccoli, respectively. The same authors further emphasize that CARB content reflects the amount of calories, and thus low CARB levels in food are an advantage for weight reduction diets. Fibers help control the intestine, whereas PTN are crucial for the growth and development of the human body. Ash levels reflect the amount of minerals present in the food, which is usually around $1 \%$. Moisture content depends on the degree of plant maturity and it is usually higher than $80 \%$. On the other hand, LIP levels are minimal in these crops.

In cabbage, Ferreira et al. (2014) observed the following traits: total titratable acidity $=1.03 \%$, carbohydrates $=2.77 \%$, and total soluble solids $=$ $5.56^{\circ}$ Brix. The same authors state that the identification of plant nutritional composition can help create preparation techniques of several recipes. However, the maintenance of nutritional quality depends on the adoption of measures that control the production of the raw material (Chitarra \& Chitarra, 2005).

The conventional production system of these vegetables is based on intensive soil preparation, highly soluble mineral fertilizers, and intensive use of agrochemicals (Silva et al., 2012). Also, high genetic potential of modern cultivars make them highly dependent on such industrialized inputs.

These crops demand high amounts of nutrients (Oliveira et al., 2005). However, Altieri \& Nicholls (2003) point out that cultivation practices that involve high amounts of inorganic fertilizers can cause nutritional imbalances in plants and reduce the quality of the final product.

A way to reduce the amounts of fertilizers and agrochemicals in the production of vegetables is the cultivation of cover crops. The residues of such crops release nutrients during the process of decomposition, which then become available for subsequent crops, and which also help suppress the germination of voluntary plants (Carvalho et al., 2011).

Studying no-till broccoli (Neves et al., 2014), cabbage (Perin et al., 2015; Torres et al., 2015), and cauliflower (Torres et al., 2015) on residues of brachiaria and millet, the researchers observed an increase in head diameter and crop yield when compared to the conventional system.

Studies have also shown that brachiaria, sunn hemp, millet and fallow (spontaneous vegetation) are well adapted to the soil and climate conditions in the Cerrado, and that they produce high volume of green and dry cover, thus contributing considerable amounts of nutrients to the soil (Torres \& Pereira, 2014).

Another way to add nutrients to the soil is the use of organic fertilization via animal manure or vermicompost. Brassicas respond well to organic fertilization when used as a substitute for mineral fertilizers, which can contribute to the sustainability of the production of vegetables in the Cerrado (Silva et al., 2012).

Some studies have evaluated agronomic performance of Brassica crops cultivated under no-till system, but there are only few evaluations of physico-chemical changes in these crops when grown on cover crop residues. These parameters are important from the nutritional point of view, as well as for processing, storage and transport. In this context, this study evaluated the chemical composition and yield of notill cabbage and cauliflower cultivated on the residues of various cover crops, in the municipality of Uberaba, Minas Gerais State, Brazil.

\section{MATERIAL AND METHODS}

This study was conducted from December 2012 to September 2013 in the experimental area of the Federal Institute of Triângulo Mineiro (19 39'19"S, 47 $57^{\circ} 27^{\prime}$ 'W, altitude $795 \mathrm{~m}$ ), located in the municipality of Uberaba.

The soil of the experimental area was characterized as Dystrophic Red Latosol (Embrapa, 2006) of medium texture, and smooth \& undulating relief. The $0.00-0.20 \mathrm{~m}$ soil layer contained: $210 \mathrm{~g}$ clay $/ \mathrm{kg}, 710 \mathrm{~g}$ sand $/ \mathrm{kg}, 80 \mathrm{~g}$ silt/ $\mathrm{kg}, \mathrm{pH} \mathrm{CaCl}_{2} 5.5 ; 76 \mathrm{mg} / \mathrm{dm}^{3}$ of $\mathrm{P}($ resin); $2 \mathrm{mmol} / \mathrm{dm}^{3}$ of $\mathrm{K}^{+} ; 22 \mathrm{mmol}_{\mathrm{c}} / \mathrm{dm}^{3}$ of $\mathrm{Ca}^{2+} ; 10 \mathrm{mmol} / \mathrm{cm}^{3}$ of $\mathrm{Mg}^{2+} ; 17 \mathrm{mmol}_{\mathrm{c}} /$ $\mathrm{dm}^{3}$ of $\mathrm{H}+\mathrm{Al}$, and $19 \mathrm{~g} / \mathrm{dm}^{3}$ of organic matter, $V=67 \%$. According to the Köppen classification, the climate in the region is classified as Aw-tropical, with hot and rainy summer and cold and dry winter. The annual averages of rainfall, temperature and relative humidity in the region are: $1,600 \mathrm{~mm}, 22.6^{\circ} \mathrm{C}$ and $68 \%$, respectively (Uberaba in data, 2009). During the study period, precipitation occurred in the months of April (167.7 $\mathrm{mm})$, May (97.9 mm), June (37.1 mm), and July $(14.8 \mathrm{~mm})$. Precipitation in November $(190.4 \mathrm{~mm})$ and December $(224.7 \mathrm{~mm})$ was lower than usual, which is not common in the region.

The experimental design was randomized blocks with four cover crops: sunn hemp (Crotalaria juncea); brachiaria (Urochloa brizantha cv marandu), millet ADR 500 (Pennisetum glaucum), fallow (spontaneous vegetation with predominance of Poaceae); and two main crops: cauliflower cv Sharon and cabbage cv Astrus plus. The treatments were carried out on plots of $20 \mathrm{~m}^{2}(4.0 \times 5.0 \mathrm{~m})$ with 4 replications.

Prior to the experiment, the area was plowed, harrowed and planted with soybeans. The crop was harvested at the end of March 2012. After soybeans harvest, the area was left fallow until the implementation of the experiment. In December 2012, cover plants (brachiaria, sunn hemp and millet) were sown with row spacing of $0.45 \mathrm{~m}$ and 50 , 25 , and 50 seeds per meter, respectively. In March 2013, when more than 50\% of 
the plants reached maximum flowering, the cover crops were desiccated with $1440 \mathrm{~g} / \mathrm{ha}$ of glyphosate $+600 \mathrm{~g} / \mathrm{ha}$ of paraquat.

To evaluate dry matter (DM), samples were collected from an area of $2 \mathrm{~m}^{2}$ per plot, then dried at $65^{\circ} \mathrm{C}$ for 72 hours and weighed. Seven days after desiccation, the cover plants were cut with brush cutter close to the soil and left on soil surface.

Cauliflower cv Sharon and cabbage cv Astrus plus are the most popular cultivars among the producers in the region of Triângulo Mineiro, and therefore their seeds were acquired. Seedlings were produced in polystyrene trays of 128 cells containing the commercial substrate Plantmax ${ }^{\circledR}$. At the beginning of April 2013, the seedlings $(10-15 \mathrm{~cm}$ high) were transplanted to pits spaced $0.8 \times 0.4 \mathrm{~m}$ apart. Three central rows were used for crop evaluation.

The plants were irrigated daily, keeping the soil moisture close to the field capacity. The irrigation system was based on fixed conventional spraying nozzles spaced 9 meters apart and flow of $560 \mathrm{~L} / \mathrm{h}$. Irrigation time was approximately 20 minutes. Weeds were removed manually.

Before transplanting of the seedlings, half of the recommended fertilizer dose (10 t/ha) with organic compound (composted cattle manure) was applied into the pits.

Mineral fertilizer dose for the crops was based on soil analysis and the recommendation of the Soil Fertility Commission of the State of Minas Gerais (1999). Half of the dose was applied and the other half was expected to come from decaying plant residues of the cover crops. Both cauliflower and cabbage were fertilized with the following doses: $100 \mathrm{~kg} / \mathrm{ha}$ of $\mathrm{P}_{2} \mathrm{O}_{5}$, $100 \mathrm{~kg} / \mathrm{ha}$ of $\mathrm{K}_{2} \mathrm{O}$, and $150 \mathrm{~kg} / \mathrm{ha}$ of $\mathrm{N}$, which were split into 3 applications: at planting, 30, and 45 days after planting. Also, $1 \mathrm{~g}$ of boric acid $(17.5 \% \mathrm{~B})$ per pit was applied.

Cauliflower was harvested when the inflorescences were completely developed, the flower buds were still united and compact, and the heads were firm. Initiated 90 days after sowing, the harvest lasted 30 days with evaluations carried out every three days. Cabbage was harvested when the firmness of the heads reached commercial acceptance, which began 100 days after sowing and lasted 20 days.

After harvest, all plants were taken to the laboratory of food analysis at the IFTM, Campus Uberaba, for evaluations of moisture (MO), lipids (LIP), crude fiber (CF), proteins (PTN), carbohydrates (CARB), total soluble solids (TSS), total titratable acidity (TTA), $\mathrm{pH}$, ascorbic acid (AA), head fresh weight (HFW), head dry weight (HDW), an yield. Evaluations of the traits were carried out using the following methods: $\mathrm{MO}=$ gravimetric method; PTN $=$ Kjeldahl method for nitrogen determination in food following the methodology described by AOAC (2005); $\mathrm{CF}=$ gravimetric method after digestion in acid medium using the methodology of the Adolfo Lutz Institute (2008); $\mathrm{LIP}=$ the Soxhlet method (gravimetric) based on the amount of the material solubilized by the solvent; $\mathrm{AA}=$ the Tillmans method (AOAC, 2005). The fixed mineral residue was determined by calcination of the sample in muffle at $550^{\circ} \mathrm{C}$, until obtaining clear ash.

Total titratable acidity and acidity in predominant acid were determined using the methodology of Instituto Adolfo Lutz (2008), pH using pH meter with sample at $25^{\circ} \mathrm{C}$; TSS by electronic refractometry, CARB by calculation of difference, and total caloric value by calculating the caloric value of each constituent of the food. The analyzes of PTN, CF and LIP were done on dry samples; later indices were calculated for fresh matter. The remaining analyzes were carried out on fresh samples 24 hours after harvest, keeping them refrigerated and packed in five layers of nylon bags during this period, following the methodology described by AOAC (2005).

The data were submitted to analysis of variance, using the statistical program SISVAR. The F test was applied for significance and the means were compared by the Tukey test at $5 \%$ probability.

\section{RESULTS AND DISCUSSION}

Dry matter production in the treatment with millet $(8.6 \mathrm{t} / \mathrm{ha})$ and fallow (8.6 t/ha) were equal, but higher $(\mathrm{p}<0.05)$ than in the treatment with brachiaria (6.5 t/ha) and sunn hemp (4.6 t/ha), respectively.

These crops are commonly used for the production of DM in the Cerrado. In the summer, brachiaria, millet, and sunn hemp produce 6.0-13.0 t/ha, 7.0-12.0 t/ ha, and 4.0-9.0 t/ha of DM, respectively, while in the winter their yields decrease to 2.0-3.0 t/ha, 2.0-4.0 t/ha, and 3.5-5.3 t/ha, respectively (Torres et al. , 2008), and 2.1-5.5 t/ha for fallow at any time of the year (Carvalho et al., 2011; Torres \& Pereira, 2014).

High content of DM in cover crops provides excellent soil cover, which can alter soil moisture and temperature, maintain or increase organic matter content, and consequently influence nutrient cycling because of residue decomposition, mainly $\mathrm{N}$ and $\mathrm{K}$ due to their high mobility in soil and plants (Torres et al., 2008; Crusciol \& Soratto, 2009; Vargas et al., 2011).

Head fresh weight (1.0 and $1.2 \mathrm{~kg}$ ), head dry weight (73.4 and $74.1 \mathrm{~g}$ ) and yield (7.3 and $8.2 \mathrm{t} / \mathrm{ha}$ ) of cauliflower were higher $(p<0.05)$ than on the fallow treatment when cultivated on brachiaria and sunn hemp residues (Table 1). For cabbage, HFW (2.8 kg), HDW (0.65 g) and yield (19.2 t/ha) were higher $(p<0.05)$ when grown on brachiaria residues. This is probably due to rapid decomposition and cycling of nutrients left by brachiaria and sunn hemp, as verified in studies carried out on the same site (Torres et al., 2008; Torres \& Pereira, 2008, 2014).

In studies conducted under similar climate and soil conditions, Morais Junior et al. (2012) observed that cauliflower cv. Sharon reached HFW of $1.5 \mathrm{~kg}$ and yield of $30.7 \mathrm{t} / \mathrm{ha}$, which is higher than in our study. For cabbage, the values ranged from 2.1 to $2.8 \mathrm{~kg}$, which is higher than $1.3 \mathrm{~kg}$ reported by Oliveira et al. (2005) and similar to 2.3 $\mathrm{kg}$ reported by Vargas et al. (2011), all grown on sunn hemp residues.

Cauliflower cultivars with larger and heavier heads are more valued on the market, as they fall into the upper classes of the classification standards for commercialization. Various weights 
Table 1. Agronomic characteristics: HFW= head fresh weight; HDW= head dry weight; and head yield of cauliflower and cabbage on different cover crop residues. Uberaba, IFTM, 2013.

\begin{tabular}{lccccccc}
\hline \multirow{2}{*}{$\begin{array}{l}\text { Cover } \\
\text { crops }\end{array}$} & $\begin{array}{c}\text { HFW } \\
(\mathbf{k g})\end{array}$ & $\begin{array}{c}\text { HDW } \\
(\mathbf{g})\end{array}$ & $\begin{array}{c}\text { Yield } \\
(\mathbf{t} / \mathbf{h a})\end{array}$ & & $\begin{array}{c}\text { HFW } \\
(\mathbf{k g})\end{array}$ & $\begin{array}{c}\text { HDW } \\
(\mathbf{g})\end{array}$ & $\begin{array}{c}\text { Yield } \\
(\mathbf{t} / \mathbf{h a})\end{array}$ \\
\hline Brachiaria & $1.0 \mathrm{a}$ & $73.4 \mathrm{a}$ & $7.3 \mathrm{a}$ & & $2.8 \mathrm{a}$ & $0.65 \mathrm{a}$ & $19.2 \mathrm{a}$ \\
Sunn hemp & $1.2 \mathrm{a}$ & $74.1 \mathrm{a}$ & $8.2 \mathrm{a}$ & & $2.1 \mathrm{~b}$ & $0.66 \mathrm{a}$ & $14.7 \mathrm{~b}$ \\
Millet & $0.9 \mathrm{~b}$ & $60.4 \mathrm{~b}$ & $5.9 \mathrm{~b}$ & & $2.4 \mathrm{~b}$ & $0.53 \mathrm{~b}$ & $16.8 \mathrm{~b}$ \\
Fallow & $0.8 \mathrm{~b}$ & $54.6 \mathrm{~b}$ & $5.3 \mathrm{~b}$ & & $2.1 \mathrm{~b}$ & $0.46 \mathrm{~b}$ & $14.8 \mathrm{~b}$ \\
\hline F & $2.395^{*}$ & $1.741^{*}$ & $2.392^{*}$ & & $2.265^{*}$ & $2.203^{*}$ & $2.263^{*}$ \\
CV (\%) & 22.00 & 19.40 & 22.01 & & 14.91 & 19.78 & 14.92 \\
DMS & 0.05 & 12.97 & 1.76 & & 0.16 & 0.11 & 2.20 \\
\hline
\end{tabular}

*Significant, 5\% (significativo, 5\%); means followed by same letters in the column do not differ $(\mathrm{p}<0.05)$.

have been reported for this trait, however the ideal HFW is considered to be 1.0$2.0 \mathrm{~kg}$ for this cultivar. According to Monteiro et al. (2010), the same does not occur for cabbage, since the standards demanded by the Brazilian consumer market are between 1.0 and $1.5 \mathrm{~kg}$ of HFW.

Physico-chemical analysis of cauliflower revealed significant differences $(p<0.05)$ among cover crops. The levels of LIP $(0.16 \%)$, PTN (1.36\%), CARB (5.66\%), TSS $\left(4.99^{\circ}\right.$ Brix $)$ and TTA $(2.98 \%)$ were significantly different $(p<05)$ when the crop was grown on sunn hemp residues (Table 2). This was probably due to high levels of available $\mathrm{N}$ in the soil, which had previously been fixed by this crop, as verified in other studies (Torres et al., 2008; Carvalho et al. 2011; Perin et al., 2015). However, pH (5.76), AA (2.62 $\mathrm{mg} / 100 \mathrm{~g})$ and $\mathrm{CF}(1.28 \%)$ were not affected by cover crops. Also, ash levels did not differ among the cover crops.

Crude fiber content in cauliflower ranged from 1.28 to $1.95 \%$, and the highest level was recorded for plants cultivated on brachiaria residues $(1.95 \%)$. This is still lower when compared to $2.4 \%$ reported by Storck et al. (2013), who analyzed fiber content in several foods and observed levels ranging from 0.72 to $16.02 \%$. These authors state that such variations occur due to high variability of CF content in foods.

Lipid content in cauliflower ranged from 0.12 to $0.16 \%$, and the highest content was found in plants cultivated on sunn hemp residues. However, they were still below the $1.0 \%$ registered by Gondim et al. (2005). This is probably due to the fact that fruits and vegetables are not natural sources of LIP, which are highly energetic molecules found in plant and animal tissues. Lipids carry electrons, transport substances involved in enzymatic reactions, make up the biological membranes, and store energy (Somerville et al., 2000).

Analyzing chemical composition of cauliflower inflorescence, Storck et al. (2013) found $1.9 \%$ of PTN and $4.5 \%$ of CARB, which is higher than recorded in our study (1.36 and $5.66 \%$, respectively). The same authors emphasize the importance of PTN contents in food, since it is a fundamental nutrient for the growth and development of the human body. CARB levels show low calorie content in the plant, which can be an advantage in alimentation since these plants can be used in any type of diet.

In a study carried out by Ornellas (2007), the author points out that broccoli and cauliflower are morphologically similar, whose nutritional value varies according to the part of the plant, and which contains on average $1-3 \%$ of PTN and $4-24 \%$ of CARB.

Regarding TSS content (expressed in ${ }^{\circ}$ Brix), the value of 4.99 observed for cauliflower on sunn hemp residues is probably related to high levels of available $\mathrm{N}$ and $\mathrm{K}$ provided through biological fixation and later through decomposition process and nutrient cycling, as proven by Torres et al. (2008) and Torres \& Pereira (2008).

Soluble sugars present in fruits and vegetables in combined forms are responsible for sweetness, flavor and color, which may vary due to climatic factors, variety, soil and water addition during processing (Santos et al., 2004).

Table 2. Physico-chemical characteristics: $\mathrm{MO}=$ moisture, $\mathrm{ASH}=$ ash, $\mathrm{CF}=$ crude fiber, $\mathrm{LIP}=$ lipids, $\mathrm{PTN}=$ proteins, $\mathrm{CARB}=$ carbohydrates, $\mathrm{TTA}=$ titratable acidity, $\mathrm{TSS}=$ total soluble solids, $\mathrm{pH}$ and $\mathrm{AA}=$ ascorbic acid of cauliflower grown after different cover crops. Uberaba, IFTM, 2013.

\begin{tabular}{|c|c|c|c|c|c|c|c|c|c|c|}
\hline $\begin{array}{l}\text { Cover } \\
\text { crops }\end{array}$ & $\begin{array}{l}\text { MO } \\
\text { (\%) }\end{array}$ & $\begin{array}{c}\text { ASH } \\
(\mathrm{g})\end{array}$ & $\begin{array}{l}\text { CF } \\
\text { (g) }\end{array}$ & $\begin{array}{l}\text { LIP } \\
(\%)\end{array}$ & $\begin{array}{l}\text { PTN } \\
(\%)\end{array}$ & $\begin{array}{c}\text { CARB } \\
(\%)\end{array}$ & $\begin{array}{l}\text { TTA } \\
(\%)\end{array}$ & $\begin{array}{c}\text { TSS } \\
\left({ }^{\circ} \mathrm{Brix}\right)\end{array}$ & pH & $\begin{array}{c}\mathbf{A A} \\
(\mathrm{mg} / \mathbf{1 0 0 g}\end{array}$ \\
\hline Brachiaria & $92.3 \mathrm{a}$ & $0.92 \mathrm{a}$ & $1.95 \mathrm{a}$ & $0.12 b$ & $1.30 \mathrm{a}$ & $3.45 \mathrm{c}$ & $2.43 b$ & $3.66 b$ & $5.81 \mathrm{~b}$ & $5.26 \mathrm{a}$ \\
\hline Sunn hemp & $90.2 \mathrm{a}$ & $1.31 \mathrm{a}$ & $1.28 \mathrm{~b}$ & $0.16 \mathrm{a}$ & $1.36 \mathrm{a}$ & $5.66 \mathrm{a}$ & $2.98 \mathrm{a}$ & $4.99 a$ & $5.76 \mathrm{~b}$ & $2.62 \mathrm{c}$ \\
\hline Millet & $92.3 \mathrm{a}$ & $0.85 \mathrm{a}$ & $1.49 \mathrm{ab}$ & $0.15 \mathrm{a}$ & $1.13 \mathrm{c}$ & $4.11 \mathrm{~b}$ & $1.84 \mathrm{c}$ & $3.83 b$ & $5.86 \mathrm{~b}$ & $5.26 \mathrm{a}$ \\
\hline Fallow & $91.7 \mathrm{a}$ & $1.09 \mathrm{a}$ & $1.80 \mathrm{ab}$ & $0.12 b$ & $1.25 \mathrm{~b}$ & $4.05 \mathrm{~b}$ & $1.88 \mathrm{c}$ & $3.25 \mathrm{~b}$ & $6.00 \mathrm{a}$ & $3.95 \mathrm{~b}$ \\
\hline DMS & 1.82 & 0.48 & 0.61 & 0.05 & 0.11 & 1.87 & 1.12 & 0.68 & 0.23 & 2.42 \\
\hline CV (\%) & 0.83 & 25.6 & 20.7 & 19.9 & 3.6 & 17.2 & 13.2 & 6.16 & 1.61 & 13.5 \\
\hline
\end{tabular}

Means followed by same letters in the column do not differ $(\mathrm{p}<0.05)$. 
Table 3. Physico-chemical characteristics: $\mathrm{MO}=$ moisture, $\mathrm{ASH}=$ ash, $\mathrm{CF}=$ crude fiber, $\mathrm{LIP}=$ lipids, $\mathrm{PTN}=$ proteins, $\mathrm{CARB}=$ carbohydrates, $\mathrm{TTA}=$ titratable acidity, TSS $=$ total soluble solids, and AA= ascorbic acid of cabbage grown after different cover crops. Uberaba, IFTM, 2013.

\begin{tabular}{|c|c|c|c|c|c|c|c|c|c|c|}
\hline Cover crops & $\begin{array}{l}\text { MO } \\
(\%)\end{array}$ & $\begin{array}{c}\text { ASH } \\
\text { (g) }\end{array}$ & $\begin{array}{l}\text { CF } \\
\text { (g) }\end{array}$ & $\begin{array}{l}\text { LIP } \\
(\%)\end{array}$ & $\begin{array}{l}\text { PTN } \\
(\%)\end{array}$ & $\begin{array}{c}\text { CARB } \\
(\%)\end{array}$ & $\begin{array}{l}\text { TTA } \\
(\%)\end{array}$ & $\begin{array}{c}\text { TSS } \\
\left({ }^{\circ} \text { Brix }\right)\end{array}$ & pH & $\begin{array}{c}\mathrm{AA} \\
(\mathbf{m g} / \mathbf{1 0 0 g})\end{array}$ \\
\hline Brachiaria & $92.6 \mathrm{a}$ & $0.06 \mathrm{a}$ & $0.92 \mathrm{a}$ & $0.04 \mathrm{a}$ & $1.15 b$ & $5.21 \mathrm{a}$ & $5.59 \mathrm{a}$ & $5.65 \mathrm{a}$ & $6.37 \mathrm{a}$ & $21.0 \mathrm{a}$ \\
\hline Sunn hemp & $92.8 \mathrm{a}$ & $0.06 \mathrm{a}$ & $0.84 \mathrm{a}$ & $0.05 \mathrm{a}$ & $1.33 \mathrm{a}$ & $4.86 \mathrm{a}$ & $4.76 b$ & $5.62 \mathrm{a}$ & $6.34 \mathrm{a}$ & $8.93 b$ \\
\hline Millet & $93.4 \mathrm{a}$ & $0.05 \mathrm{a}$ & $0.82 \mathrm{a}$ & $0.05 \mathrm{a}$ & $1.15 b$ & $4.48 \mathrm{a}$ & $4.93 b$ & $5.41 \mathrm{a}$ & $6.38 \mathrm{a}$ & $8.87 \mathrm{~b}$ \\
\hline Fallow & $93.1 \mathrm{a}$ & $0.06 \mathrm{a}$ & $0.80 \mathrm{a}$ & $0.06 \mathrm{a}$ & $1.16 \mathrm{~b}$ & $4.48 \mathrm{a}$ & $4.19 \mathrm{c}$ & $5.31 \mathrm{a}$ & $6.43 \mathrm{a}$ & $4.48 \mathrm{c}$ \\
\hline DMS & 1.34 & 0.34 & 0.45 & 0.03 & 0.08 & 1.38 & 0,82 & 0.51 & 0.17 & 1.78 \\
\hline CV (\%) & 0.91 & 10.90 & 5.45 & 11.50 & 1.25 & 5.40 & 3.75 & 4.69 & 6.02 & 12.50 \\
\hline
\end{tabular}

Means followed by same letters in the column do not differ $(\mathrm{p}<0.05)$ (letras iguais na coluna não diferem, $5 \%)$.

Sunn hemp residues decreased $\mathrm{pH}$ and increased TTA for cauliflower relative to the control treatment, which according to Fernandes et al. (2008) can be considered normal for this crop. These authors point out that as the harvest period approaches, citric acid and acidity levels decrease. They also emphasize that $\mathrm{pH}$ tends to increase with the decrease of the acidity in some crops.

Ascorbic acid content in cauliflower cultivated on brachiaria $(5.26 \mathrm{mg} / 100$ g) and millet $(5.26 \mathrm{mg} / 100 \mathrm{~g})$ residues was significantly higher when compared to sunn hemp ( $2.62 \mathrm{mg} / 100 \mathrm{~g})$ residues and fallow $(3.95 \mathrm{mg} / 100 \mathrm{~g})$, which could have increased protection against oxidation in this crop, as also observed by Coultate (2004).

Analysis of cabbage leaves demonstrated significant differences $(\mathrm{p}<0.05)$ among evaluated cover crops. Protein level $(1.33 \%)$ was low $(\mathrm{p}<0.05)$ when the crop was grown on sunn hemp residues, whereas TTA $(5.79 \%)$ and AA $(21.0 \mathrm{mg} / 100 \mathrm{~g})$ levels were high $(p<0.05)$ on brachiaria residues relative to other cover crops (Table 3 ).

Regarding PTN, its level was significantly high $(\mathrm{p}<0.05)$ when the crop was cultivated on sunn hemp residues $(1.33 \%)$. For the other cover crops, its levels ranged between 1.15 and $1.16 \%$, but still between 1 and $3 \%$, as highlighted by Ornellas (2007). High availability of $\mathrm{N}$ in the soil provided by sunn hemp probably increased protein concentration in cabbage, since $\mathrm{N}$ favors photosynthesis and stimulates cell division, thus increasing total protein content in the plant (Marschner, 1995).

Levels of TTA $(5.59 \%)$ and AA $(20.96 \mathrm{mg} / 100 \mathrm{~g})$ were high $(\mathrm{p}<0.05)$ when the crop was cultivated on brachiaria residues relative to other cover crops, which were $4.19-4.93 \%$ for TTA and 4.48-8.93 mg/100 g for AA.

These TTA levels express total hydrogen content, while $\mathrm{pH}$ reflects the concentration of ionized hydrogen in the fruit or vegetable pulp, which can lead to large variations in TTA without appreciable variations in $\mathrm{pH}$ (Chitarra \& Chitarra, 2005). During storage periods, when TTA and $\mathrm{pH}$ are high, there is probably a higher concentration of citric acid and AA in undissociated form.

The highest levels of PTN (1.33\%) in cabbage also occurred in treatment on sunn hemp residues, probably due to high availability of $\mathrm{N}$ (Torres et al., 2008) and K (Torres \& Pereira, 2008). According to Vallverdú-Queralt et al. (2012), cabbage naturally presents high nutritive value and high concentrations of calcium, PTN and AA, especially when higher concentrations of $\mathrm{N}$ are available in the soil.

Regarding TSS content expressed in ${ }^{\circ}$ Brix, no significant difference was observed. However, the levels found in our study were higher than those reported by Rinaldi et al. (2009), who found soluble solids content ranging from 2 to $5^{\circ}$ Brix in minimally processed cabbage. Also, analyzing the composition in minimally processed white cabbage (Brassica oleracea), Ferreira et al. (2014) observed TTA of $1.03 \%$, CARB of $2.77 \%$ and TSS of $5.56^{\circ}$ Brix.

Cabbage produced high level of AA $(21.0 \mathrm{mg} / 100 \mathrm{~g})$ when grown on brachiaria residues. This characteristic favors the maintenance of identity and quality standards (IQS) of a product to be consumed for a longer period. Manolopoulou \& Varzakas (2011) also found that IQS of cabbage was maintained for 14 days when stored at $0^{\circ} \mathrm{C}$, and for 7 days when stored at $5^{\circ} \mathrm{C}$. According to Oms-Oliu et al. (2010), some substances, among them AA, are antioxidants, which prevent enzymatic browning, loss of taste and aroma, maturation of tissues and loss of nutritional quality.

Cultivation of cauliflower and cabbage on residues of cover crops positively altered most of the chemical attributes of the crops when compared to the fallow treatment, with the best yield and AA levels observed when the crops were cultivated on brachiaria residues.

The cultivation of cauliflower and cabbage on brachiaria, millet and sunn hemp residues showed promising results, since they positively altered most of the chemical attributes of evaluated crops. The best productivity and chemical attributes occurred when the crops were cultivated on brachiaria residues.

When cultivated on sunn hemp residues, cauliflower produced significantly higher levels of LIP, PTN, CARB, TSS and acidity, while on brachiaria and millet residues AA levels were higher than in other treatments.

Regarding cabbage, its cultivation on brachiaria residues significantly increased acidity and AA, whereas for PTN the best cover crop was sunn hemp.

\section{ACKNOWLEDGEMENTS}

The authors thank the Federal Institute of the Triângulo Mineiro 
Physico-chemical attributes of no-till Brassica crops cultivated after various cover crops

Uberaba campus for the infrastructure provided, Fapemig and the Agrisus Foundation for granting scholarship to the students and financing of the project.

\section{REFERENCES}

ALTIERI, MA; NICHOLLS, CI. 2003. Soil fertility management and insect pests: harmonizing soil and plant health in agroecosystems. Soil \& Tillage Research, 72: 203-211.

AOAC - ASSOCIATION OF OFFICIAL ANALYTICAL CHEMISTRY. 2005. Official methods of analysis of the Association of Official Analytical Chemistry. 18 ed. Washington. 1015p.

CARVALHO, AM; SOUZA, LLP; GUIMARÃES JÚNIOR, R; ALVES, PCAC; VIVALDI, LJ. 2011. Cover plants with potential use for crop-livestock integrated systems in the Cerrado region. Pesquisa Agropecuária Brasileira 46: 1200-1205.

CARVALHO, C; KIST, BB; POLL, H. 2013. Anuário brasileiro de hortaliças. Santa Cruz do Sul: Editora Gazeta Santa Cruz. 88p.

CHITARRA, MIF; CHITARRA, AB. 2005. Póscolheita de frutas e hortaliças: fisiologia e manuseio. 2. ed., Lavras: UFLA. 785p.

COMISSÃO DE FERTILIDADE DO SOLO DO ESTADO DE MINAS GERAIS. 1999. Recomendações para o uso de corretivos e fertilizantes em Minas Gerais: $5^{a}$ aproximação. Viçosa: CFSEMG. 359p.

COULTATE, TP. 2004. Alimentos: A química de seus componentes. $3^{\mathrm{a}}$ ed. Porto Alegre: Artmed. 368p.

CRUSCIOL, CAC; SORATTO, RP. 2009. Nitrogen supply for cover crops and effects on peanut grown in succession under a no-till system. Agronomy Journal 101: 40-46.

EMBRAPA, Centro Nacional de Pesquisa de solos. 2006. Sistema brasileiro de classificação de solos. 2a ed. Rio de Janeiro: Embrapa. 306p.

FERNANDES, AF; PEREIRA, J; GERMANI, R; OIANO-NETO, J. 2008. Efeito da substituição parcial da farinha de trigo por farinha de casca de batata (Solanum Tuberosum L). Ciência Tecnologia de Alimentos 28: 56-65.

FERREIRA, TA; SILVA, CO; PASCOAL, GB. 2014. Analise físico-química em repolho branco (Brassica oleraceae) minimamente processado durante o acondicionamento sob refrigeração. Linkania 01: 59-72.

GONDIM, JAM; MOURA, MFV; DANTAS, AS; MEDEIROS, RLS; SANTOS, KM. 2005. Composição centesimal e de minerais em cascas de frutas. Ciência e Tecnologia de
Alimentos 25: 825-827.

INSTITUTO ADOLFO LUTZ - IAL. 2008. Métodos físico-químicos para análises de alimentos. $4^{\circ}$ ed. São Paulo: IAL. 1020p.

MANOLOPOULOU, E; VARZAKAS T. 2011. Effect of storage conditions on the sensory quality, color and texture of freshcut minimally processed cabbage with the addition of ascorbic acid, citric acid and calcium chloride. Food and Nutrition Sciences, 2: 956-963.

MARSCHNER, H. 1995. Mineral nutrition of higher plants. $2^{\circ}$ ed. New York: Academic Press. 889p.

MONTEIRO, BCBA; CHARLO, HCO; BRAZ, LT. 2010. Desempenho de híbridos de couveflor de verão em Jaboticabal. Horticultura Brasileira, 28: 115-119.

MORAIS JUNIOR, PO; CARDOSO, AF; LEÃO, EF; PEIXOTO, N. 2012. Desempenho de cultivares de couve-flor de verão em Ipameri. Ciência Rural 42: 1923-1928.

NEVES, JS; SILV, LB; SEABRA JUNIOR, S; NEVES, SMA; NEVES, RJ; DASSOLLER, TF. 2014. Cultivo de hortaliças sobre plantio direto e coberturas do solo em Cáceres/MT. Caderno de Agroecologia 9: 1-8.

OLIVEIRA, FL; RIBAS, RGT; JUNQUEIRA RM; PADOVAM, MP; GUERRA, JGM; ALMEIDA, DL; RIBEIRO, RLD. 2005. Desempenho do consórcio entre repolho e rabanete com pré-cultivo de crotalária, sob manejo orgânico. Horticultura Brasileira 23: 184-188.

OMS-OLIU, G; ROJAS-GRAÜ, MA; GONZÁLEZ, LA; VARELA, P. 2010. Recent approaches using chemical treatments to preserve quality of fresh-cut fruit: a review. Postharvest Biology and Technology 57: 139-148.

ORNELLAS, HL. 2007. Seleção e preparo de alimentos. 8. ed. São Paulo: Atheneu. p.158164.

PERIN, A; CRUVINEL, DA; FERREIRA, HS; MELO, GB; LIMA, LE; ANDRADE, JWS. 2015. Decomposição da palhada e produção do repolho em sistema de plantio direto. Global Science and Technology 8: 153-159.

RINALDI, MM; BENEDETTI, BC; SARANTÓPOULOS, CIGL; MORETTI, CL. 2009. Estabilidade de repolho minimamente processado sob diferentes sistemas de embalagem. Ciência e Tecnologia de Alimentos 29: 310-315.

SANTOS, FA; SALLES, JRJ; CHAGAS FILHO, E; RABELO, RN. 2004. Análise qualitativa das polpas congeladas de frutas produzidas pela SUFRUTS, MA. Revista Higiene Alimentar 18:14-22.

SILVA, KS; SANTOS, ECM; BENETT, CGS;
LARANJEIRA, LT; EBERHARDT NETO, E; COSTA, E. 2012. Produtividade e desenvolvimento de cultivares de repolho em função de doses de boro. Horticultura Brasileira 30: 520-525.

SOMERVILLE, CC; BROWSE, J; JAWORSKI, JG; OHLROGGE, JB. 2000. Lipids. In: BUCHANAN, B; GRUISSEM, W; JONES, R. Biochemistry \& Molecular Biology of Plants. Rockville: American Society of Plant Phsyiologists. p.456-458.

STORCK, CR; NUNES, GL; OLIVEIRA, BB; BASSO, C. 2013. Folhas, talos, cascas e sementes de vegetais: composição nutricional, aproveitamento na alimentação e análise sensorial de preparações. Ciência Rural 43: 537-543.

TORRES, JLR; ARAUJO, AS; BARRETO, AC; SILVA NETO, OF; SILVA, VR; VIEIRA, DMS. 2015. Desenvolvimento e produtividade da couve-flor e repolho influenciados por tipos de cobertura do solo. Horticultura Brasileira 33: 510-514.

TORRES, JLR; PEREIRA, MG. 2008. Dinâmica do potássio nos resíduos vegetais de plantas de cobertura no Cerrado. Revista Brasileira de Ciência do Solo 32: 1609-1618.

TORRES, JLR; PEREIRA, MG. 2014. Produção e decomposição de resíduos culturais antecedendo milho e soja num Latossolo no cerrado mineiro. Comunicata Scientiae 5: 419-426.

TORRES, JLR; PEREIRA, MG; FABIAN, AJ. 2008. Produção de fitomassa por plantas de cobertura e mineralização de seus resíduos em plantio direto. Pesquisa Agropecuária Brasileira 43: 421-428.

UBERABA EM DADOS. 2009. Prefeitura Municipal de Uberaba. 23p. Disponível: <http: www.uberaba.mg.gov.br/portal/ acervo/desenvolvimento/arquivos/uberaba em_dados/Edicao_2009/Capitulo01.pdf.> Acessado em 21.02.2014.

VALLVERDÚ-QUERALT, A; MEDINAREMÓN, A; CASALS-RIBES, I; LAMUELARAVENTOS, RM. 2012. Is there any difference between the phenolic content of organic and conventional tomato juices? Food Chemistry 130: 222-227.

VARGAS, TO; DINIZ, ER; SANTOS, RHS; LIMA, CTA; URQUIAGA, S; CECON, PR. 2011. Influência da biomassa de leguminosas sobre a produção de repolho em dois cultivos consecutivos. Horticultura Brasileira 29: 562-568. 